\title{
The Effects of Absorptive Capacity, Intellectual Property and Innovation in SMEs
}

\author{
Luis Enrique Valdez Juárez ${ }^{1}$, Elba Alicia Ramos Escobar ${ }^{1}$ \& Gonzalo Maldonado Guzmán ${ }^{2}$ \\ ${ }^{1}$ Faculty of Business Administration, Technological Institute of Sonora (Mexico), Sonora, Mexico \\ ${ }^{2}$ Faculty of Economics and Business, Autonomous University of Aguascalientes (Mexico), Aguascalientes, \\ Mexico \\ Correspondence: Luis Enrique Valdez Juárez, Faculty of Business Administration, Technological Institute of \\ Sonora (Mexico), Sonora, Mexico. E-mail: levaldez@itson.edu.mx or gmaldona@correo.uaa.mx
}

Received: June 9, 2017 Accepted: July 12, 2017 Online Published: October 25, 2017

doi:10.5539/jms.v7n4p36 URL: http://doi.org/10.5539/jms.v7n4p36

\begin{abstract}
The ability to learn and acquire knowledge has been one of the most important challenges for most companies, and especially for SMEs. The purpose of this study was to examine the effects of absorptive capacity on innovation, market orientation, and intellectual property management in SMEs. We also analyzed the influence of these variables on financial results in SMEs. The study was based on a sample of 412 companies in the industrial (manufacturing and agro-industry) and services (telecommunications and real estate) sectors operating in the Mexican Northwest. Data collection was carried out from June to October, 2014, using self-directed interviews with company managers. The estimation of relationships was tested by variance-based SEM statistical method with the PLS technique, using the SmartPLS software (version 3.2.6). Results showed that absorptive capacity has a significant influence on innovation and market orientation. Moreover, innovation and market orientation were found to have a significant influence on business profitability. No empirical support was found to explain the relationship between intellectual property management and absorptive capacity, innovation, and SME profitability. SME managers should continue with internal and external training of employees to strengthen their skills and knowledge. In addition, they must adopt and implement a business model that connects knowledge with intellectual property and innovation, through an $R \& D$ department, in order to increase profitability. With these actions the companies through their managers will have employees with greater skills, knowledge and with greater creativity. Leading to the SMEs to take advantage of its capabilities to develop new products, patent processes and products and protect their knowledge. It is also important for managers to continue to implement marketing strategies that allow them to become more competitive global markets. With the market focus companies can compete in global markets and achieve sustained profitability. This study is a contribution to absorptive capacity literature and to the resource-based view.
\end{abstract}

Keywords: absorptive capacity, innovation, market orientation, profitability, SME (Industrial and services sectors operating Mexican Northwest)

\section{Introduction}

The business world of today is teeming with constant technological, economic, and sociopolitical changes, and for individual companies, knowledge has become a determining factor in achieving a sustained competitive advantage (Nonaka, Kodama, Hirose, \& Kohlbacher, 2014). The RVB, along with the absorptive capacity (AC) theory, are the company's avenues to success and organizational development (Barney, 2001; Cohen \& Levinthal, 1990). By nature, small and medium-sized companies usually focus their resources and capacities inwards, seeking product development, while frequently overlooking opportunities such as acquiring knowledge about their external environment (Teece, 2007). Activities aimed at absorbing knowledge from the exterior are a key factor in increasing innovation (INNO) and, in turn, creating an environment of organizational learning (Zahra \& George, 2002). Over the past two decades, literature has explored AC by means of models incorporating the capture, assimilation, transformation, and use of knowledge within organizations (Nonaka et al., 2014; Teece, 2009). These dimensions have been the foundations to consolidate companies, and have supported their adaptation to changes in the market (Nonaka, 2008). Current organizations require competitive advantages, which can be acquired by employing their capacities and resources (Teece, 2007). Crucial attributes such as knowledge, innovation capacity, and a focus on the market are the center of attention and starting point towards 
significant financial results (Allameh \& Abbas, 2011). For SMEs, it is also important to acquire external knowledge, and to efficiently assimilate, transform, and exploit such knowledge (Zahra \& George, 2002). However, a gap in this area has been a recurring problem in most of these organizations (Bagnoli \& Vedovato, 2014). The main obstacles to establishing an efficient knowledge absorption system are: lack of strategic planning, insufficient capital investment, poor technological infrastructure, and underqualified human capital (OECD, 2014; Raymond, Bergeron, Croteau, \& St-Pierre, 2016) These barriers have prevented SMEs from adopting a learning system based on (internal and external) knowledge, improving innovation activities, and competing in global markets (Augier \& Teece, 2009). Additionally, a predominantly short-termed vision and deficient organizational culture have failed to promote significant investment in research and development (R\&D) (Falkner \& Hiebl, 2015). In SMEs, these organizational practices have resulted in intellectual property (IP) management problems and poor outcomes in innovation and financial results (Amidon \& Macnamara, 2004; Crema \& Verbano, 2016).

During the empirical literature review, we found an important number of studies analyzing the relationship between absorptive capacity and enterprise innovation and performance (Caragliu \& Nijkamp, 2012). However, most of these studies have analyzed the effect of such variables in large companies. There are also few studies analyzing the influence of absorptive capacity, innovation, and intellectual property management on market orientation (MO) and on profitability (PROF) in SMEs (Najafi-Tavani, Sharifi, \& Najafi-Tavani, 2016; Spithoven, Clarysse, \& Knockaert, 2011). These variables, which analyze organizational learning modes, also focus on large organizations and organizational knowledge (Chen, Lin, \& Chang, 2009). Frequently, these studies compare regions based on technological level, amount of inventions, knowledge protection practices, and open and disruptive innovation (Spithoven et al., 2011; Wonglimpiyarat, 2015). The present study has three main objectives: the first is to analyze the influence of $\mathrm{AC}$ on innovation, intellectual property, and market orientation in SMEs; the objective is to analyze the relation between innovation, intellectual property, and MO on SME profitability, and the last objective is to analyze the role played by intellectual property management in the SME learning model.

\subsection{Research Questions}

The following are the research questions of the present study:

1) Does absorptive capacity have an influence on intellectual property management, market orientation, and innovation in SMEs?

2) Does innovation have an influence on intellectual property management, market orientation, and profitability in SMEs?

3) Do market orientation and intellectual property management have an influence on profitability in SMEs?

This article is structured as follows: The first part presents a literature review and an empirical review, as well as the hypotheses development. Secondly, the method, the sample and their characteristics are described, and the study variables are justified. Finally, we present the results, discussion, and research conclusions.

\section{Literature and Development of Hypotheses}

\subsection{Absorptive Capacity and Innovation in SMEs}

Literature has stressed that the way in which a company's learning mode and its capacity to capture knowledge have been differentiators in current markets (Lichtenthaler, 2009). These attributes have been described by AC theory, which has become one of the most important approaches to enterprise growth and development (Caragliu \& Nijkamp, 2012; Todorova \& Durisin, 2007). Since its creation, the theory has conceptualized AC as the capacity companies have to detect new knowledge and the value of new external information, as well as how to assimilate it and use it with commercial purposes (Cohen \& Levinthal, 1990). Additionally, AC theorists have proposed internal and external knowledge as an effective means to increase creativity and innovation capacity and to foster intellectual property practices (Zahra \& George, 2002). Similarly, the RBV stresses knowledge generated by companies as a key survival element in order to adapt themselves to market demands (Barney, 2001). Some studies have confirmed the effectiveness of AC in complicated scenarios, for instance financial crises, to drive innovation and growth in SMEs (Liao, Welsch, \& Stoica, 2003). Other researchers have reported that companies that take a collaborative approach to working with other companies achieve a higher development of human capital capacities by absorbing external knowledge and improving their innovation outlook (Camisón \& Forés, 2010; Nguyen, 2017). Recently, the importance of AC has been explored in association with knowledge management and teamwork practices, which have allowed for the development of new products, the improvement of processes, and the increase in SME profitability (Leal-Rodríguez, 
Ariza-Montes, Roldán, \& Leal-Millán, 2014; Spithoven et al., 2011). Therefore:

\section{H1. Higher absorptive capacity increases the level of innovation in the SME.}

\subsection{Absorptive Capacity and Market Orientation in SMEs}

In regard to the effects of absorptive capacity on market orientation, some studies have confirmed that a company's knowledge, seen as a learning system, has serious implications for markets: when knowledge about the market and the clients is insufficient, companies have severe disadvantages in their sectors (Lichtenthaler, 2009). AC has also been shown to play the role of a moderating and determinant variable in the design of new products, the improvement of existing products, and the development of new ways to commercialize products or services (Spithoven et al., 2011). This business strategy is focused on regional and international market orientation and on activities aimed at innovating products and processes (Ahimbisibwe, Nkundabanyanga, Nkurunziza, \& Nyamuyonjo, 2016; Najafi-Tavani et al., 2016).

\section{H2. Higher absorptive capacity increases the level of market orientation in the SME.}

\subsection{Absorptive Capacity and Intellectual Property Management in SMEs}

Absorptive capacity in companies has been frequently associated with an increase in individual and organizational knowledge. The result has implications in the activities derived from innovation, and especially on knowledge management, reflected by human capital and intellectual property activities (Ayerbe, Lazaric, Callois, \& Mitkova, 2014). Despite knowledge capture, assimilation, and knowledge usage practices are usually not fully developed in SMEs, there are studies demonstrating the significant relationship between absorptive capacity, innovation, and intellectual capital (protection of knowledge) (Cassol, Gonçalo, \& Ruas, 2016). Companies have also been shown to achieve the transformation of their internal and external knowledge into intangible assets, such as the development of new products, the increase in brand value, and the development of patents, which results in encouraging expectations in highly competitive markets (Ayerbe et al., 2014). Moreover, experts are beginning to regard absorptive capacity, organizational innovation, and open innovation as the most effective means to generate intangible assets and to develop intellectual property in SMEs (Lin, Wu, Chang, Wang, \& Lee, 2012; Raymond et al., 2016). Accordingly, we have developed the following hypothesis:

\section{H3. Higher absorptive capacity increases the level of intellectual property management in the SME.}

\subsection{Innovation, Intellectual Property, and Market Orientation}

Although innovation capacity represents opportunities for organizations, it can also be a risk factor for SMEs (Brunswicker \& Vanhaverbeke, 2015). Companies see innovation as the openness to new ideas and the capacity to adapt themselves to change (Lichtenthaler, 2009). Innovation exploits ideas and converts knowledge into profitable products, processes, or services with increased value for clients (Johannessen \& Olsen, 2010). By using new technologies and open innovation, companies in different regions protect their organizational knowledge, product and process design, inventions, and commercial branding (Chen \& Puttitanun, 2005). These actions allow companies to focus more effectively on the market. Market orientation is the approach taken by the company in regard to clients, competitors, and agents of influence so as to meet its own demands and necessities (Kirca, Bearden, \& Roth, 2011). The mix of a company's resources and capabilities are its most important instrument to direct their innovation efforts towards current and potential markets (Adner \& Kapoor, 2010; Chesbrough, 2010). This ideas led to the following hypothesis:

\section{H4. Increased innovation practices result in increased intellectual property management in the SME}

The development of new products, licenses, and patents enable organizations of all sizes to reach new markets while satisfying the demands of their current clients (Terziovski, 2010). Most studies focused on the relation between innovation and market orientation have stated that developing new products and improving production and service processes have made significant contributions to client satisfaction and competitive advantage (Low, Chapman, \& Sloan, 2007). Other work asserts that technology-based innovation represents an incalculable value to the client: it helps to meet their expectations, improves relationships, and helps the company to rediscover future market needs (Raju, Lonial, \& Crum, 2011). SMEs that orient their resources and capacities, for instance their knowledge and product and process innovation, towards market orientation, obtain a strong competitive advantage over other companies and survive in complicated and turbulent environments (Guzmán, Castro, \& Serna, 2013; Naidoo, 2010). Innovation and intellectual property have also been associated as mediators towards a more precise market orientation (Cassol et al., 2016; Naidoo, 2010). Some SMEs have approached research centers and universities in order to improve their intellectual property management in diverse endeavors: brand and logo design, improvement of production processes, patent registration, and they are also demanding the design of platforms to control, transfer, and protect knowledge, to control client information, and to analyze 
market trends as efforts aimed at improving competitiveness (Doh \& Kim, 2014; Rappert, Webster, \& Charles, 1999). Therefore:

\section{H5. Increased innovation practices lead to increased market orientation in the SME}

H6. More intense intellectual property management increases the level of market orientation in the SME.

\subsection{Innovation, Intellectual Property, Client Orientation, and Performance}

The RBV emphasizes the (internal and external) resources of a company, as well as its capacities (such as knowledge and innovation), as determining factors in market competitiveness and company performance (Barney, 1991). It has also been demonstrated that innovation leads to new added-value products, processes, and management systems that have a positive impact on client satisfaction and company performance (Rosenbusch, Brinckmann, \& Bausch, 2011). Additionally, it has been shown that innovation results in incremental and radical changes favorable to competitiveness and profitability in SMEs (Madrid-Guijarro, García-Pérez-de-Lema, \& Van Auken, 2013; Rosenbusch et al., 2011). Recent studies have reported that incorporating organizational innovation in the SME translates into significant improvements in products and processes, which in turn increases sales and improves economic results (Brunswicker \& Vanhaverbeke, 2015). Another organizational strategy or attribute with influence on results as financial performance is market orientation. Different empirical studies have found that SMEs are redirecting their efforts towards market orientation by satisfying customer needs, adding accuracy to their analysis of competitors, and providing their employees with knowledge: their purpose is to increase competitiveness, productivity, and business profits (Kumar, Jones, Venkatesan, \& Leone, 2011; Walker, Brewer, Boyne, \& Avellaneda, 2011). Moreover, scholars in the field of innovation and intellectual capital (intellectual property) have shown that these activities result in faster return on investment, as well as in increased sales, economic growth, and profitability in SMEs (Crema \& Verbano, 2016; Falkner \& Hiebl, 2015). Based on these ideas, we developed the following hypothetical statements:

\section{H7. Increased innovation practices lead to increased profitability levels in the SME}

\section{H8. More significant market orientation leads to higher profitability levels in the SME}

H9. More intense intellectual property management leads to increased profitability levels in the SME

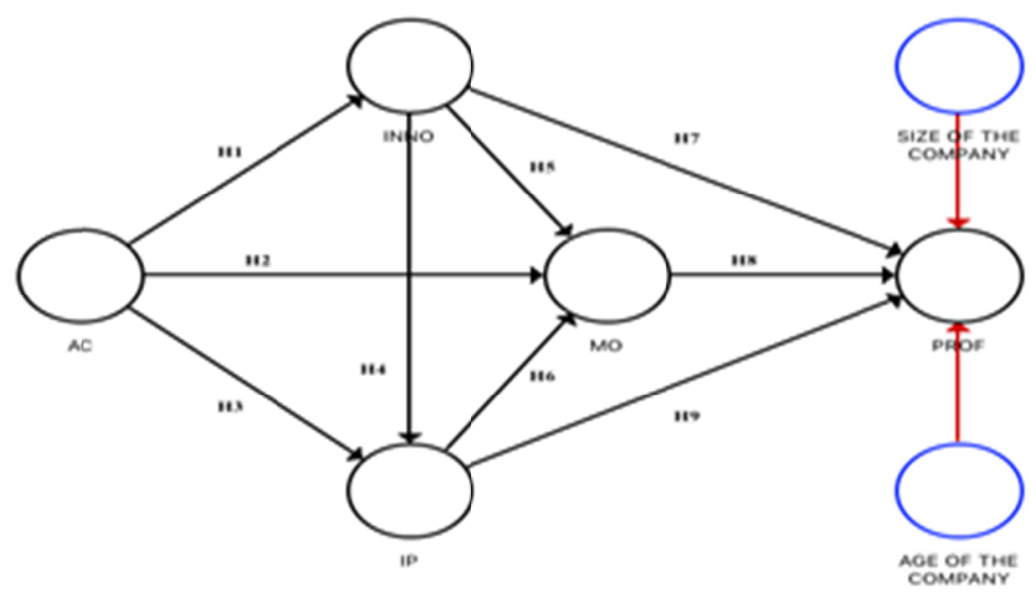

Figure 1. Theoretical model

\section{Methodology}

The sample was structured according to the principles of finite population stratified sampling. The population consisted of SMEs in the industrial (manufacturing and agro-industry) and services (telecommunications and real estate) sectors established in the Mexican Northwest, which were grouped according to their type of activity. The number of companies in each strata was based on information from the Economic Census carried out by the Mexican National Institute for Statistics and Geography (INEGI, 2014). Sample size was determined so that the maximum margin of error when estimating a proportion (relative frequency of response to a specific item in a question) was less than 0.03 points, with a 95\% confidence level. Information was gathered by means of personal interviews (questionnaires) with SME managers. The first section of the questionnaire registered 
general data of the company and the interviewee. The second section includes questions about each one of the study variables: absorptive capacity, innovation, intellectual property, market orientation, and performance (see tables $2,3,4,5$, and 6). Field work took place from June to October, 2014. The final sample included 412 companies, $80.6 \%$ from the industrial sector and $19.4 \%$ from the services sector. The composition and characteristics of the sample can be appreciated in tables 1 and 7.

Table 1. Age and size of the companies

\begin{tabular}{lllllc}
\hline Economic activity & Sector & \# of companies & Small enterprises & Medium-sized enterprises & \% total \\
\hline Agro-industrial & Industrial & 202 & 185 & 14 & 49.0 \\
Maquiladora (manufacturing) & Industrial & 130 & 40 & 90 & 31.6 \\
Telecommunications & Services & 50 & 50 & 3 & 12.1 \\
Real estate & Services & 30 & 30 & 0 & 7.3 \\
Total & & 412 & 305 & 107 & 100.0 \\
\hline
\end{tabular}

Note. SE: Small enterprise (10 to 50 employees) ME: Medium-sized enterprise (10 to 250 employees).

\subsection{Variable Measurement}

The present study used reflective variables; the main feature of this type of model is that direction and influence flow from the construct to the indicator. The observed indicators or variables are a reflection or expression of the construct, which is not observed except into a relationship (Bollen \& Lennox, 1991; Jarvis, MacKenzie, \& Podsakoff, 2003). Reflective variables are characterized by high correlations among all the indicators (co-variation), which are interchangeable; adding a new indicator does not alter the content of the construct (Jarvis et al., 2003; Wetzels, Odekerken-Schröder, \& Van Oppen, 2009).

Absorptive Capacity. The literature offers different models to measure the impact of this variable in organizations; the most important of these models derive from Cohen and Levinthal's theory (Cohen \& Levinthal, 1990). For instance, Zahra \& George (2002) and Teece (2007) focus their studies in the capacity to acquire knowledge within and outside an organization for its future exploitation in the context of innovation and profitability activities. SME managers were asked to respond the following questions, which were written based on our theoretical and empirical review; the questions dealt with the study variables and responses were registered in a five-point Likert scale ( $1=$ totally disagree, $5=$ totally agree). AC encompasses: (1) Acquisition of internal and external knowledge, as measured by four items and adapted from Gold \& Arvind Malhotra (2001); (2) Knowledge transfer, as measured by two items and adapted from Camisón \& Forés (2010), and (3) Use of knowledge, as measured by two items and adapted from Zahra \& George (2002) (see table 2).

Table 2. Internal consistency and convergent validity by construct

\begin{tabular}{llll}
\hline Absorptive Capacity & FL & CR & CA \\
\hline Knowledge is acquired: & & $\mathbf{0 . 9 2 1}$ & $\mathbf{0 . 9 0 1}$ \\
From competitors, clients, and suppliers/providers & $0.831^{* * *}$ & & \\
From universities and government entities & $0.742^{* * *}$ & & \\
From mutual collaboration among employees & $0.793^{* * *}$ & & \\
From working methods and new product design & $0.731^{* * *}$ & \\
New knowledge is transferred by means of: & & \\
New technologies for sharing knowledge among employees & $0.765^{* * *}$ & \\
Written manuals and procedures & $0.769^{* * *}$ & \\
Knowledge is used for: & & & \\
Developing new products and services & $0.779^{* * *}$ & & \\
Implementing market and business strategies & $0.739^{* * *}$ & & \\
\hline
\end{tabular}

Note. $\mathrm{FL}=$ Factor loading, $\mathrm{CR}=$ Composite reliability, $\mathrm{CA}=$ Cronbach's alpha.

Innovation. This variable was measured using models by the OECD (2005) and Teece (2009); the questionnaire asks managers to indicate whether their SME had incorporated innovation in past years $(1=$ Yes, $0=$ No $)$ and how important innovation activities were for their companies. A five-point Likert scale was also used here $(1=$ Not important at all, 5=Very important). The measurement of this variable consisted of: (1) Product innovation, as measured by two questions; (2) Process innovation, as measured by three questions, and (3) Management system innovation, as measured by two questions (See table 3). 
Table 3. Internal consistency and convergent validity by construct

\begin{tabular}{|c|c|c|c|}
\hline Innovation & FL & $\mathrm{CR}$ & $\mathrm{CA}$ \\
\hline Over the past two years, there were significant changes and improvements in: & & 0.947 & 0.935 \\
\hline Products or services & $0.862 * * *$ & & \\
\hline Commercialization & $0.875^{* * *}$ & & \\
\hline Business processes & $0.891 * * *$ & & \\
\hline Company direction and management & $0.802 * * *$ & & \\
\hline Purchasing and provision have contributed to management systems & $0.793 * * *$ & & \\
\hline Product sales for improved profitability & $0.848 * * *$ & & \\
\hline Product design for improved competitiveness & $0.860 * * *$ & & \\
\hline
\end{tabular}

Note. $\mathrm{FL}=$ Factor loading, $\mathrm{CR}=$ Composite reliability, $\mathrm{CA}=$ Cronbach's alpha.

Market orientation. A wide range of instruments and scales to measure market orientation can be found in the literature. We analyzed the models developed by Kohli, Jaworski, \& Kumar (1993) and the MARKOR scale, improved and adapted by Matsuno, Mentzer, \& Özsomer (2002). These models and scales have been the principal references for measuring the importance of $\mathrm{MO}$ in businesses as a function of organizational innovation results. SME managers were asked to respond to three structured questions in the questionnaire to score the degree of importance of the effects of MO over the two years previous to the study in their SME; again, a five-point Likert scale was used ( $5=$ Not important at all, $5=$ Very important) (see table 4 ).

Table 4. Internal consistency and convergent validity by construct

\begin{tabular}{llll}
\hline Market Orientation & FL & CR & CA \\
\hline Your company: & & $\mathbf{0 . 8 8 2}$ & $\mathbf{0 . 7 9 9}$ \\
Satisfies market demands & $0.841^{* * *}$ & & \\
Promptly responds to competitors' actions & $0.857^{* * *}$ & & \\
Offers the best products or services in the sector & $0.835^{* * *}$ & & \\
\hline
\end{tabular}

Note. $\mathrm{FL}=$ Factor loading, $\mathrm{CR}=$ Composite reliability, $\mathrm{CA}=$ Cronbach's alpha.

Intellectual property. In the literature, we identified a classification of intellectual property in human capital, customer capital, and structural capital (Bontis, 1998; Ordóñez de Pablos, 2004). The study of intellectual capital is divided in two schools of thought, respectively focused on strategy and measurement (Roos \& Roos, 1997). The strategic school is centered on the analysis of the creation and use of collective knowledge by simultaneously studying the relation between knowledge and value creation; the measurement school stresses the need for an information system to quantify non-financial data (Petty \& Guthrie, 2000). The reference for the following questions were Bontis, Bart, Nazari, \& Herremans (2007) theory on human capital and the models developed by WIPO (2004) on intellectual property in connection with absorptive capacity and innovation. The SME managers were asked to respond six items about IP management: 1. Brand registration, 2. Patent registration, 3. Advertisement registration, 4. New product design, 5. Process registration, and 6. Utility model design, indicating its degree of importance for their company over the past two years. A five-point Likert scale was also used here ( $1=$ Not important at all, $5=$ Very important $)$ (See table 5$)$.

Table 5: Internal consistency and convergent validity by construct

\begin{tabular}{llll}
\hline Intellectual Property & FL & CR & CA \\
\hline Your company develops and manages: & & $\mathbf{0 . 9 2 3}$ & $\mathbf{0 . 9 0 3}$ \\
Brand registration & $0.919^{* * *}$ & & \\
Patent registration & $0.945^{* * *}$ & & \\
Advertisement registration & $0.828^{* * *}$ & & \\
New product design & $0.736^{* * *}$ & & \\
Process registration & $0.718^{* * *}$ & & \\
Utility model design & $0.737^{* * *}$ & & \\
\hline
\end{tabular}

Note. $\mathrm{FL}=$ Factor loading, $\mathrm{CR}=$ Composite reliability, $\mathrm{CA}=$ Cronbach's alpha.

Performance. Objective performance measures, such as return on assets, sales performance, and return on capital have inherent problems due to their short-term scope, lack of adjustment for risk, and difficulty in associating them with a specific innovation (Geyskens, Gielens, \& Dekimpe, 2002); accounting measurements 
are also based on historical costs, and therefore, may not accurately reflect the future (Kalyanaram, Robinson, \& Urban, 1995). Managers' responses were employed to classify SME competitiveness based on profitability results using a five-point Likert scale (1=poor performance over past two years, $5=$ high performance over past two years). This variable was measured using questions adapted from Quinn \& Shapiro (1991) and Smith \& Smith (2007).

Table 6 . Internal consistency and convergent validity by construct

\begin{tabular}{llll}
\hline Profitability & FL & CR & CA \\
\hline Over the past two years, your company: & & $\mathbf{0 . 9 0 7}$ & $\mathbf{0 . 8 7 7}$ \\
Satisfied customer needs & $0.817^{* * *}$ & & \\
Adapted itself to market needs and market changes & $0.793^{* * *}$ & & \\
Held their products or services in good esteem & $0.798^{* * *}$ & & \\
Increased market quota & $0.768^{* * *}$ & & \\
Increased profitability & $0.795^{* * *}$ & & \\
Increased sales & $0.745^{* * *}$ & & \\
\hline
\end{tabular}

Note. $\mathrm{FL}=$ Factor loading, $\mathrm{CR}=$ Composite reliability, $\mathrm{CA}=$ Cronbach's alpha.

\subsection{Control Variables}

Size of the company. This variable was measured using the natural logarithm of total number of employees during 2013. This variable has been traditionally and frequently used in empirical studies due to its importance as a parameter of business development and business growth (Bagnoli \& Vedovato, 2014; Benitez-Amado \& Walczuch, 2012). The structural size of the company is deemed as an important factor in the generation of economic and financial performance (Jensen \& Peng, 2013; Sigler, 2011). Age of the company. Empirical studies frequently analyze this control variable within business models and associate it with economic and financial results in order to determine the influence of organizations over a set period of time (Bagnoli \& Vedovato, 2014; Benitez-Amado \& Walczuch, 2012). Company age determines how consolidated and mature a company is in the context of a market explained by the evolutionary theory (Nelson \& Winter, 2009). This variable is measured from the beginning of the company's operation to its current activities.

Table 7. Company's age and size

\begin{tabular}{lllll}
\hline Characteristic & Minimum & Maximum & Mean & $\begin{array}{l}\text { Typical } \\
\text { Deviation }\end{array}$ \\
\hline Age of the company & 1 & 98 & 10.62 & 10,887 \\
Size of the company (number of employees) & 10 & 244 & 45.02 & 52,684 \\
\hline
\end{tabular}

\subsection{Reliability and Validity}

Instrument reliability and validity was determined using a structural equation model (SEM) to avoid measurement and multicollinearity errors (Hair Jr, Black, Babin, Anderson, \& Tatham, 2010). Our study analyzed the variables in the theoretical model using a variance-based SEM, which was the best fit for our own model and research objectives. The partial least squares (PLS) method was utilized to account for the relationships between research variables with a variance-based SEM approach (Barclay, Higgins, \& Thompson, 1995; Hair Jr, Hult, Ringle, \& Sarstedt, 2013). Using the PLS method involves two phases (Barclay et al., 1995; Ringle, Sarstedt, \& Straub, 2012): Measurement model and structural model. Measurements are based on confirmatory factor analysis (CFA) in order to disregard indicators with low correlation in comparison with the rest of the scale. Additionally, we analyzed internal consistency, convergent validity, and discriminant validity (Fornell \& Larcker, 1981).

\section{Results}

\subsection{Measurement Model}

With the aim of assessing the measurement model with reflective variables we analyzed the composite reliability, internal consistency, and convergent validity of each item. (Carmines \& Zeller, 1991; Chin \& Dibbern, 2010; Roberts, Priest, \& Traynor, 2006) recommend a standardized factor loading greater than 0.707 to measure the individual relation and reliability of each item; our results were in the range between 0.688 and 0.946 , close to and above 0.707 . In our model, we decided to include the loading value of 0.688 for the following reasons: 1 . It 
is significant at a level of $0.001 ; 2$. It is very close to the acceptance threshold of $0.707 ; 3$. This item is very important to secure construct validity (Wang, Chen, \& Benitez-Amado, 2015). The composite reliability analysis resulted in values in the range from 0.889 to 0.947 , which meets the requirement of values greater than 0.80 for indicators as proposed by Nunnally (1978) and Vandenberg \& Lance (2000) for basic research. Cronbach's alpha is considered satisfactory when above 0.70 (Hair, Black, Babin, Anderson, \& Tatham, 2006). Our results were in the range between 0.833 and 0.935 , which represents high construct reliability. Average variance extracted (AVE) indicates the mean amount of variance explained by the construct indicators. Our AVE values ranged from 0.59 to 0.71 . These results are above the 0.50 threshold as proposed by Hair Jr et al. (2010). Finally, the discriminant validity of the constructions in the model was verified by analyzing AVE square root. The results (diagonal) of the vertical and horizontal AVE are below the correlation between constructs. No anomalies were detected by this test (see table 8). Therefore, our results reflect adequate validity and reliability (both convergent and discriminant).

Table 8. Discriminant validity of the theoretical model

\begin{tabular}{lllllll}
\hline Construct & AVE & INNO & PROF & AC & MO & IP \\
\hline INNO & $\mathbf{0 . 7 1 9}$ & $\mathbf{0 . 8 4 8}$ & & & & \\
PROF & $\mathbf{0 . 6 1 8}$ & 0.710 & $\mathbf{0 . 7 8 6}$ & & & \\
AC & $\mathbf{0 . 5 9 2}$ & 0.694 & 0.721 & $\mathbf{0 . 7 6 9}$ & & \\
MO & $\mathbf{0 . 7 1 4}$ & 0.630 & 0.258 & 0.652 & $\mathbf{0 . 8 4 5}$ & \\
IP & $\mathbf{0 . 6 7 0}$ & 0.120 & 0.245 & 0.139 & 0.249 & $\mathbf{0 . 8 1 9}$ \\
\hline
\end{tabular}

\subsection{Structural Model}

The variance-based statistical technique of structural equations was employed to validate the hypotheses behind our investigation; we used the SmartPLS Professional software (version 3.2.6) (Ringle, Wende, \& Becker, 2014). This application is an adequate choice for exploratory and confirmatory investigation (Chin, 2010; Urbach \& Ahlemann, 2010). Table 9 and figure 2 shows $\beta$ coefficient results, degree of significance, and importance of value distribution using Student's t. Hypotheses were tested by the bootstrap procedure with 5000 subsamples, as recommended by Chin (1998).

Table 9. Results of hypothesis testing

\begin{tabular}{llllll}
\hline Hypothesis & Value of Beta & T Score & P Value & $\mathbf{F}^{\mathbf{2}}$ & Accepted/Rejected \\
\hline H1. AC -> INNO & $0.794^{* * *}$ & 29.296 & 0.000 & 1.702 & Accepted \\
H2. AC -> MO & $0.393^{* * *}$ & 6.690 & 0.000 & 0.110 & Accepted \\
H3. AC -> IP & 0.119 & 1.045 & 0.296 & 0.005 & Rejected \\
H4. INNO -> IP & 0.025 & 0.114 & 0.219 & 0.001 & Rejected \\
H5. INNO -> MO & $0.299^{* * *}$ & 3.981 & 0.000 & 0.064 & Accepted \\
H6. IP -> MO & $0.158^{* * *}$ & 3.643 & 0.000 & 0.048 & Accepted \\
H7. INNO -> PROF & $0.179^{* * *}$ & 7.916 & 0.000 & 0.243 & Accepted \\
H8. MO -> PROF & $0.821^{* * *}$ & 42.248 & 0.000 & 5.038 & Accepted \\
H9. IP -> PROF & 0.015 & 1.038 & 0.299 & 0.003 & Rejected \\
\hline
\end{tabular}

Note. $*: \mathrm{p}<0.05, * *: \mathrm{p}<0.01, * * *: \mathrm{p}<0.001$. 


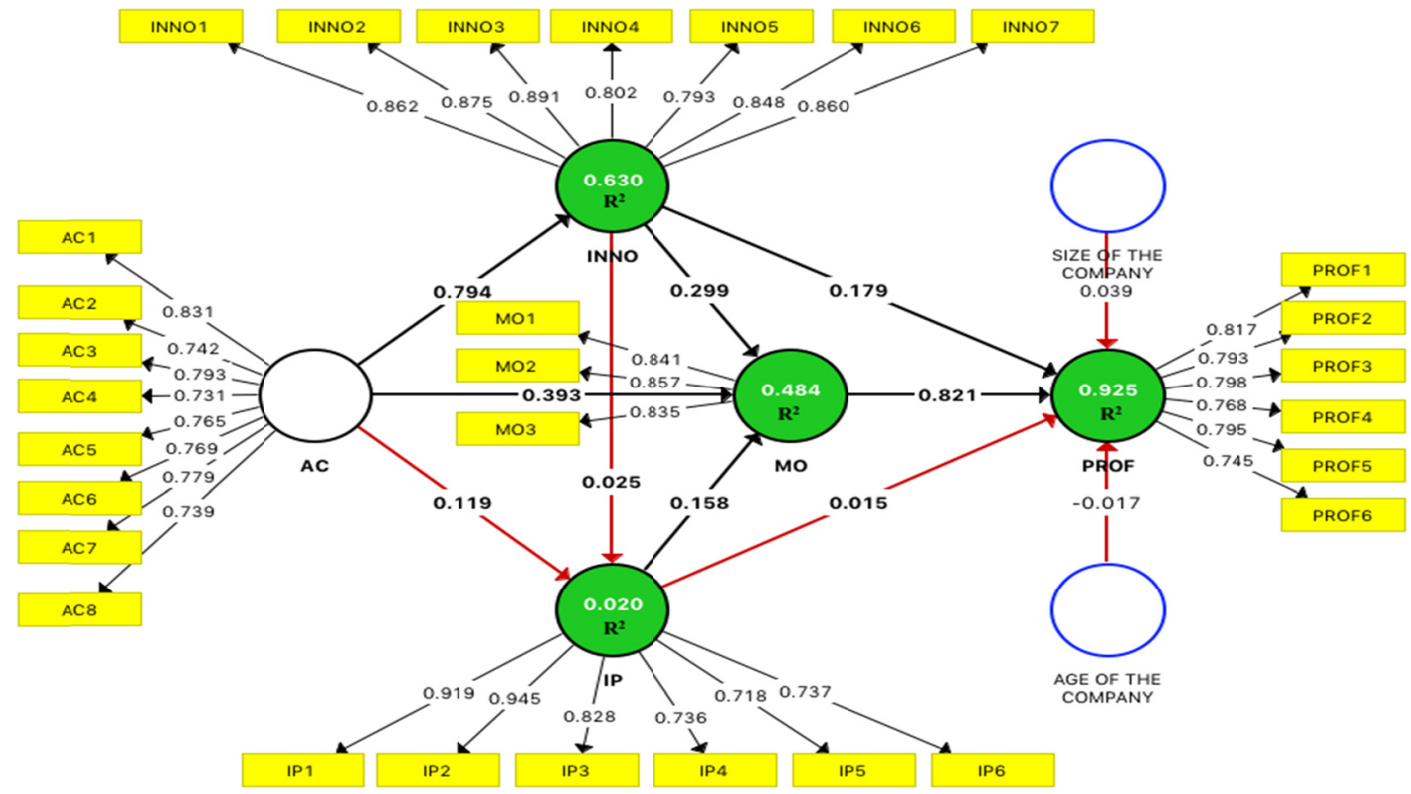

Figure 2. Research model supported by empirical data

Table 9 shows estimation results using PLS. The study found empirical support for hypotheses H1, H2, H5, H6, $\mathrm{H} 7$, and $\mathrm{H} 8$, whereas no support was found for hypotheses $\mathrm{H} 3, \mathrm{H} 4$, and $\mathrm{H} 9$. The results of hypotheses $\mathrm{H} 1$ and $\mathrm{H} 2$ showed positive and significant effects at .001 , which indicates that $\mathrm{AC}$ has a strong relationship with innovation and market orientation in SMEs, as expressed by the beta values of $0.794^{* * *}$ and $0.393^{* * *}$, respectively. Hypotheses $\mathrm{H} 5$ and $\mathrm{H} 6$, whose beta values were $0.299^{* * *}$ and $0.158^{* * *}$, respectively, indicate that innovation and intellectual property have a positive and significant influence on market orientation in SMEs. Hypotheses $\mathrm{H} 7$ and $\mathrm{H} 8$ also showed positive and significant effects in the model; which indicates that innovation and market orientation are the strongest variables and therefore the most decisive in achieving higher profitability in SMEs, as shown by its respective values of $0.179^{* * *}$ and $0.821^{* * *}$. However, hypotheses $\mathrm{H} 3, \mathrm{H} 4$, and $\mathrm{H} 9$, whose $\beta$ values were $0.119,0.025$, and 0.015 , failed to display significant effects in our model; therefore, these hypotheses were rejected. Finally, we examined the effects of the control variables (company size and company age) on performance. Our results indicated that these variables have no influence on profitability in SMEs, according to their values of $\beta=0.039$ and $\beta=-0.017$, respectively.

Whereas the evaluation of model fitting in SEM techniques is based on covariance, these measures are not possible to be estimated by PLS. However, with PLS, path coefficient, $\mathrm{R}^{2}$, and $\mathrm{F}^{2}$ values are analyzed; these are significant individual measures to determine the predictive capacity of the structural model (Chin, 2010). Path coefficients close to 0.2 are considered economically significant. The most important coefficients in our model are in the range between $0.718^{* * *}$ and $0.945^{* * *}$. The explained variance and predictive capacity of the model were analyzed by $\mathrm{R}^{2}$. The $\mathrm{R}^{2}$ results for independent variables in the model were: Innovation, 0.630; market orientation, 0.484 , and profitability, 0.925 , which indicate that the model has a high explanatory power. However, the explanatory power of the IP management variable in SMEs was found to be low $\left(R^{2}=0.020\right)$. The $F^{2}$ value indicates the size of the effect introduced in the model. $\mathrm{F}^{2}$ results showed that the key relationships of the model are in the range between 0.048 and 5.038. In general, these results show that the proposed model has adequate structural properties and good explanatory power. The $\mathrm{Q}^{2}$ cross-validated redundancy index statistical test is employed to evaluate and test the predictive relevance of endogenous constructs in structured models using reflective variables. Our model was evaluated using the blindfolding technique (Hair Jr et al., 2013), and the values were between 0.011 and 0.525 . Values higher than zero showed an outstanding predictive capacity (Hair et al., 2006). In general, this analysis evinces the adequate explanatory power of the model. To increase the precision of the predictive effect of our model, we also performed a goodness-of-fit test using PLS. Fit is acceptable when the standardized root mean square residual (SRMR) value is in the range $(<0,08-0,1)$ (Henseler et al., 2014; Henseler, Hubona, \& Ray, 2016). Our result, 0.082, confirms the acceptable predictive capacity of the model and demonstrates that the empirical results are closely related with the theory. 
Table 8. Predictive capacity and model fitting

\begin{tabular}{lll}
\hline Dimension & $\mathbf{R}^{\mathbf{2}}$ & $\mathbf{Q}^{\mathbf{2}}$ \\
\hline Innovation & 0.630 & 0.421 \\
Market Orientation & 0.484 & 0.325 \\
Intellectual Property & 0.020 & 0.011 \\
Profitability & 0.925 & 0.525 \\
\hline
\end{tabular}

\section{Discussion and Conclusion}

The literature has laid bare that AC increases creativity and innovation capacity, both key factors to achieve competitiveness and profitability in companies of all sizes (Caragliu \& Nijkamp, 2012). Knowledge, innovation, and strategic innovation focused on the market are organizational practices that help companies to penetrate competitive markets (Lichtenthaler, 2009; Porter, 2011). This section discusses our results in the light of the main theoretical perspectives on organizational practices associated with knowledge, innovation, market orientation, and company profitability. In the first part of this article we analyzed the learning system developed by SMEs by means of their capacity to absorb knowledge, their approach to innovation and intellectual property, and their market orientation practices. The most salient finding in the present study is the relationship between $\mathrm{AC}$ and innovation and market orientation practices in SMEs. These results are in line with the theory, and emphasize that the capacity to absorb knowledge and efficiently manage such knowledge enables organizations to improve the design of their products and to add value to their production processes and services (Cohen \& Olsen, 2015; Teece, 2009). The results also have a direct and positive effect on the demand in regional and global markets (Camisón \& Forés, 2010). Moreover, empirical studies point out to AC as a determining factor in the development and increase of human capital skills and capabilities, which allows companies to encourage creativity and develop innovation (Chen et al., 2009). As a result, companies address market needs more precisely and are in a better position to deal with competitors (Najafi-Tavani et al., 2016). In the second part, we analyzed the relationships among innovation and intellectual property management, market orientation, and profitability in SMEs. This analysis revealed that innovation has a strong and direct influence on market orientation and profitability. According to the RBV, companies that manage their human, technological, and financial resources more effectively, with an approach towards improving their innovation capacities, achieve better organizational and financial results, such as increased number of clients, more sales, and higher profitability (Barney, 2001; Brunswicker \& Vanhaverbeke, 2015). Innovation practices have been clearly identified as a determining factor in the attainment of economic and financial results in SMEs, which result in competitive advantage (Teece, 2007). In the third part, we analyzed the association of intellectual property management with market orientation and profitability in SMEs. We found that IP management has a direct relationship of influence with market orientation. The RBV has described how innovation practices-by means of an R\&D department, new product design, and the development of brands, patents, and industrial processes - help companies to address and better satisfy the needs of clients and consumers in current and potential markets (Chesbrough, 2010; Naidoo, 2010). Finally, no significant empirical evidence was found for relationships between AC and IP, innovation and IP, and innovation and profitability. Among the main possible reasons behind this lack of relationship is that SMEs usually lack a formal R\&D department, as well as the little attention paid by the management to IP development, since their main focus are small changes in their products seeking short-term profits (Chesbrough, 2010).

This study analyzed learning practices and systems used by SMEs to acquire knowledge, along with their innovation capacity, market-oriented practices, and level of profitability. The study was developed during a period of global economic recovery. Results show that: 1) SMEs have efficient systems to capture internal and external knowledge and to use it to improve their products and processes, and these actions have a positive impact on innovation and market orientation; 2) innovation in SMEs has an important influence on market orientation results, which in turn have a positive effect on financial results; 3) IP management has an effect on market orientation results. However, we observed that IP management is detached from the learning system, as well as the absorptive capacity and innovation activities developed in the SME.

The results of this study have important implications for the strengthening of business management in SMEs. 1. It is important for managers to provide internal and external training to their employees in order to increase their skills, develop their creativity, and reinforce their knowledge (Bratton \& Gold, 2012), 2. In order to improve innovation and intellectual property results, business owners should pursue the creation of knowledge management and a R\&D departments (Lin et al., 2012), and 3. Managers should continue working on strategies to meet client demands, rediscover new market segments, and counteract competitors' actions (Kirca et al., 2011). 
With these actions the companies through their managers will have employees with greater skills, knowledge and with greater creativity. Leading to the SMEs to take advantage of its capabilities to develop new products, patent processes and products and protect their knowledge. Moreover, with the market focus companies can compete in global markets and achieve sustained profitability. The present study has limitations, but it opens an important door into future lines of investigation. One of the limitations derives from the use of only one source of information; the data were gathered using self-reports and subjective perceptions expressed by SME business owners and managers, which may have biased the results. Secondly, the sample included companies in the industrial and services sectors only, although it could be used in other sectors. The last limitation is the measurement scales, since we only considered reflective variables with adaptations from scales used by other authors; the use of other types of variables, such as reflective-formative variables, would be advisable. In future studies, the conceptual framework should be improved by including a larger number of constructs in order to overcome the present limitations. Lastly, given the importance of AC, innovation, and $\mathrm{MO}$ as a learning system for SMEs in this new age based on the economy of knowledge and technology, new research studying knowledge management, the use of information technology, and radical innovation should be expected in the future. It is also convenient to continue making a constant evaluation of growth, development, and competitiveness of the SME over time by means of longitudinal and causal studies.

\section{References}

Adner, R., \& Kapoor, R. (2010). Value creation in innovation ecosystems: How the structure of technological interdependence affects firm performance in new technology generations. Strategic Management Journal, 31(3), 306-333. https://doi.org/10.1002/smj.821

Ahimbisibwe, G. M., Nkundabanyanga, S. K., Nkurunziza, G., \& Nyamuyonjo, D. (2016). Knowledge absorptive capacity: do all its dimensions matter for export performance of SMEs? World Journal of Entrepreneurship, $\begin{array}{llll}\text { Management and } & \text { Sustainable }\end{array}$ https://doi.org/10.1108/WJEMSD-09-2015-0041

Allameh, S. M., \& Abbas, S. K. (2011). The relationship between knowledge management practices and innovation level in organizations: case study of sub-companies of selected corporations in the city of Esfahan. Journal of Business Case Studies (JBCS), 6(1). https://doi.org/10.19030/jbcs.v6i1.861

Amidon, D. M., \& Macnamara, D. (2004). The 7 C's of knowledge leadership: Innovating our future. Handbook on Knowledge Management, 1, 539-551. Berlin: Springer. https://doi.org/10.1007/978-3-540-24746-3_28

Augier, M., \& Teece, D. J. (2009). Dynamic capabilities and the role of managers in business strategy and economic performance. Organization Science, 20(2), 410-421. https://doi.org/10.1287/orsc.1090.0424

Ayerbe, C., Lazaric, N., Callois, M., \& Mitkova, L. (2014). The new challenges of organizing intellectual property in complex industries: A discussion based on the case of Thales. Technovation, 34, 232-241. https://doi.org/10.1016/j.technovation.2014.01.001

Bagnoli, C., \& Vedovato, M. (2014). The impact of knowledge management and strategy configuration coherence on SME performance. Journal of Management \& Governance, 18(2), 615-647. https://doi.org/10.1007/s10997-012-9211-z

Barclay, D., Higgins, C., \& Thompson, R. (1995). The partial least squares (PLS) approach to causal modeling: Personal computer adoption and use as an illustration. Technology Studies, 2(2), 285-309.

Barney, J. (1991). Firm Resources and Sustained Competitive Advantage. Journal of Management, 17(1), 99-120. https://doi.org/10.1177/014920639101700108

Barney, J. B. (2001). Resource-based theories of competitive advantage: A ten-year retrospective on the resource-based view. Journal of Management, 27(6), 643-650. https://doi.org/10.1177/014920630102700602

Benitez-Amado, J., \& Walczuch, R. M. (2012). Information technology, the organizational capability of proactive corporate environmental strategy and firm performance: a resource-based analysis. European Journal of Information Systems, 21(6), 664-679. https://doi.org/10.1057/ejis.2012.14

Bollen, K., \& Lennox, R. (1991). Conventional wisdom on measurement: A structural equation perspective. Psychological Bulletin, 110(2), 305-314. https://doi.org/10.1037/0033-2909.110.2.305

Bontis, N. (1998). Intellectual capital: an exploratory study that develops measures and models. Management Decision, 36(2), 63-76. https://doi.org/10.1108/00251749810204142

Bontis, N. B., Christopher, K., Nazari, J. A., \& Herremans, I. M. (2007). Extended VAIC model: measuring intellectual capital components. Journal of Intellectual Capital, 8(4), 595-609. 
https://doi.org/10.1108/14691930710830774

Bratton, J., \& Gold, J. (2012). Human Resource Management: Theory and Practice. Berlin: Palgrave Macmillan. https://doi.org/10.1007/978-1-137-00095-8

Brunswicker, S., \& Vanhaverbeke, W. (2015). Open Innovation in Small and Medium - Sized Enterprises (SMEs): External Knowledge Sourcing Strategies and Internal Organizational Facilitators. Journal of Small Business Management, 53(4), 1241-1263. https://doi.org/10.1111/jsbm.12120

Camisón, C., \& Forés, B. (2010). Knowledge absorptive capacity: New insights for its conceptualization and measurement. Journal of Business Research, 63(7), 707-715. https://doi.org/10.1016/j.jbusres.2009.04.022

Caragliu, A., \& Nijkamp, P. (2012). The impact of regional absorptive capacity on spatial knowledge spillovers: the Cohen and Levinthal model revisited. Applied Economics, 44(11), 1363-1374. https://doi.org/10.1080/00036846.2010.539549

Carmines, E. G., \& Zeller, R. A. (1991). Reliability and viability assessment. CA: Thousand Oaks.

Cassol, A., Gonçalo, C. R., \& Ruas, R. L. (2016). Redefining the Relationship between Intellectual Capital and Innovation: The Mediating Role of Absorptive Capacity. BAR-Brazilian Administration Review, 13(4), 1-25. https://doi.org/10.1590/1807-7692bar2016150067

Chen, L., Ming-Ji, J., \& Chang, C. H. (2009). The positive effects of relationship learning and absorptive capacity on innovation performance and competitive advantage in industrial markets. Industrial Marketing Management, 38(2), 152-158. https://doi.org/10.1016/j.indmarman.2008.12.003

Chen, Y., \& Puttitanun, T. (2005). Intellectual property rights and innovation in developing countries. Journal of Development Economics, 78(2), 474-493. https://doi.org/10.1016/j.jdeveco.2004.11.005

Chesbrough, H. (2010). Business model innovation: opportunities and barriers. Long Range Planning, 43(2), 354-363. https://doi.org/10.1016/j.lrp.2009.07.010

Chin, W. W. (1998). The partial least squares approach to structural equation modeling. Modern Methods for Business Research, 295(2), 295-336.

Chin, W. W. (2010). How to Write Up and Report PLS Analyses (pp. 655-690). https://doi.org/10.1007/978-3-540-32827-8_29

Chin, W. W., \& Dibbern, J. (2010). An introduction to a permutation based procedure for multi-group PLS analysis: Results of tests of differences on simulated data and a cross cultural analysis of the sourcing of information system services between Germany and the USA Handbook of partial least squares (pp. 171-193). Berlin: Springer.

Cohen, J. F., \& Olsen, K. (2015). Knowledge management capabilities and firm performance: A test of universalistic, contingency and complementarity perspectives. Expert Systems with Applications, 42(3), 1178-1188. https://doi.org/10.1016/j.eswa.2014.09.002

Cohen, W. M., \& Levinthal, D. A. (1990). Absorptive capacity: a new perspective on learning and innovation. Administrative Science Quarterly, 128-152. https://doi.org/10.2307/2393553

Crema, M., \& Verbano, C. (2016). Managing intellectual capital in Italian manufacturing SMEs. Creativity and Innovation Management, 25(3), 408-421. https://doi.org/10.1111/caim.12074

Doh, S., \& Kim, B. (2014). Government support for SME innovations in the regional industries: The case of government financial support program in South Korea. Research Policy, 43(9), 1557-1569. https://doi.org/10.1016/j.respol.2014.05.001

Falkner, E. M., \& Hiebl, M. R. W. (2015). Risk management in SMEs: a systematic review of available evidence. The Journal of Risk Finance, 16(2), 122-144. https://doi.org/10.1108/JRF-06-2014-0079

Fornell, C., \& Larcker, D. F. (1981). Structural equation models with unobservable variables and measurement error: Algebra and statistics. Journal of Marketing Research, 382-388. https://doi.org/10.2307/3150980

Geyskens, I., Gielens, K., \& Dekimpe, M. G. (2002). The Market Valuation of Internet Channel Additions. Journal of Marketing, 66(2), 102-119. https://doi.org/10.1509/jmkg.66.2.102.18478

Gold, A. H., \& Arvindm, M., \& Albert, H. S. (2001). Knowledge management: An organizational capabilities perspective. Journal of Management Information Systems, 18(1), $185-214$. https://doi.org/10.1080/07421222.2001.11045669

Guzmán, G. M., Castro, S. Y. P., \& Serna, M. D. C. M. (2013). La adopción de la orientación al mercado en la 
PYME manufacturera de México. FAEDPYME International Review-FIR, 2(4), 10-17.

Hair Jr, J. F., Black, W. C., Babin, B. J., Anderson, R. E., \& Tatham, R. L. (2010). SEM: An introduction. Multivariate Data Analysis: A Global Perspective, 629-686.

Hair Jr, J. F., Hult, G. T. M., Ringle, C., \& Sarstedt, M. (2013). A primer on partial least squares structural equation modeling (PLS-SEM). Thousand Oaks, California: Sage Publications.

Hair, J. F., Black, W. C., Babin, B. J., Anderson, R. E., \& Tatham, R. L. (2006). Multivariate Data Analysis (Vol. 6). Upper Saddle River, NJ: Pearson Prentice Hall.

Henseler, J., Dijkstra, T. K., Sarstedt, M., Ringle, C. M., Diamantopoulos, A., Straub, D. W., . . Calantone, R. J. (2014). Common beliefs and reality about PLS: Comments on Rönkkö and Evermann (2013). Organizational Research Methods, 17(2), 182-209. https://doi.org/10.1177/1094428114526928

Henseler, J., Hubona, G., \& Ray, P. A. (2016). Using PLS path modeling in new technology research: updated $\begin{array}{lllll}\text { guidelines. Industrial Management \& Data systems, } & 116(1), \quad 2-20 .\end{array}$ https://doi.org/10.1108/IMDS-09-2015-0382

INEGI. (2014). Instituto Nacional de Estadística, Geografía E informática. Censo Económico. Retrieved from http://www.inegi.org.mx/est/contenidos/proyectos/ce/ce2014/

Jarvis, C. B., MacKenzie, S. B., \& Podsakoff, P. M. (2003). A critical review of construct indicators and measurement model misspecification in marketing and consumer research. Journal of Consumer Research, 30(2), 199-218. https://doi.org/10.1086/376806

Jensen, C., \& Peng, L. M. (2013). SMEs, Institutions, and Performance. Small and Medium Enterprises: Concepts, Methodologies, Tools, and Applications, 46.

Johannessen, J. A., \& Olsen, B. (2010). The future of value creation and innovations: Aspects of a theory of value creation and innovation in a global knowledge economy. International Journal of Information Management, 30(6), 502-511. https://doi.org/10.1016/j.ijinfomgt.2010.03.007

Kalyanaram, G., Robinson, W. T., \& Urban, G. L. (1995). Order of Market Entry: Established Empirical Generalizations, Emerging Empirical Generalizations, and Future Research. Marketing Science, 14(3_supplement), G212-G221. https://doi.org/10.1287/mksc.14.3.G212

Kirca, A. H., Bearden, W. O., \& Roth, K. (2011). Implementation of market orientation in the subsidiaries of global companies: the role of institutional factors. Journal of the Academy of Marketing Science, 39(5), 683-699. https://doi.org/10.1007/s11747-010-0234-1

Kohli, A. K., Jaworski, B. J., \& Kumar, A. (1993). MARKOR: a measure of market orientation. Journal of Marketing Research, 467-477. https://doi.org/10.2307/3172691

Kumar, V., Jones, E., Venkatesan, R., \& Leone, R. P. (2011). Is market orientation a source of sustainable competitive advantage or simply the cost of competing? Journal of Marketing, 75(1), 16-30. https://doi.org/10.1509/jmkg.75.1.16

Leal-Rodríguez, A. L., Ariza-Montes, J. A., Roldán, J. L., \& Leal-Millán, A. G. (2014). Absorptive capacity, innovation and cultural barriers: A conditional mediation model. Journal of Business Research, 67(5), 763-768. https://doi.org/10.1016/j.jbusres.2013.11.041

Liao, J., Welsch, H., \& Stoica, M. (2003). Organizational absorptive capacity and responsiveness: an empirical investigation of growth-oriented SMEs. Entrepreneurship Theory and Practice, 28(1), 63-85. https://doi.org/10.1111/1540-8520.00032

Lichtenthaler, U. (2009). Absorptive Capacity Environmental Turbulence, And The Complementary Of Organizational Learning Processes. Academy of Management Journal, 52(4), 822-846. https://doi.org/10.5465/AMJ.2009.43670902

Lin, C., Wu, Y. J., Chang, C. C., Wang, W., \& Lee, C. Y. (2012). The alliance innovation performance of R\&D alliances - the absorptive capacity perspective. Technovation, 32(5), 282-292. https://doi.org/10.1016/j.technovation.2012.01.004

Low, D. R., Chapman, R. L., \& Sloan, T. R. (2007). Inter-relationships between innovation and market orientation in SMEs. Management Research News, 30(12), 878-891. https://doi.org/10.1108/01409170710833321

Madrid-Guijarro, A., García-Pérez-de-Lema, D., \& Van Auken, H. (2013). An Investigation of Spanish SME Innovation during Different Economic Conditions. Journal of Small Business Management, 51(4), 578-601. 
https://doi.org/10.1111/jsbm.12004

Matsuno, K., Mentzer, J. T., \& Özsomer, A. (2002). The effects of entrepreneurial proclivity and market orientation on business performance. Journal of Marketing, 66(3), 18-32. https://doi.org/10.1509/jmkg.66.3.18.18507

Naidoo, V. (2010). Firm survival through a crisis: The influence of market orientation, marketing innovation and business strategy. Industrial Marketing Management, 39(8), 1311-1320. https://doi.org/10.1016/j.indmarman.2010.02.005

Najafi-Tavani, S., Sharifi, H., \& Najafi-Tavani, Z. (2016). Market orientation, marketing capability, and new product performance: The moderating role of absorptive capacity. Journal of Business Research, 69, 5059-5064. https://doi.org/10.1016/j.jbusres.2016.04.080

Nelson, R. R., \& Winter, S. G. (2009). An evolutionary theory of economic change. Harvard: Harvard University Press.

Nguyen, D. D. (2017). Designing Optimal Knowledge Base for Neural Expert Systems. International Business Research, 10(6), 137. https://doi.org/10.5539/ibr.v10n6p137

Nonaka, I. (2008). The Knowledge-Creating Company. Harvard: Harvard Business Review Press.

Nonaka, I., Kodama, M., Hirose, A., \& Kohlbacher, F. (2014). Dynamic fractal organizations for promoting knowledge-based transformation-A new paradigm for organizational theory. European Management Journal, 32(1), 137-146. https://doi.org/10.1016/j.emj.2013.02.003

Nunnally, J. (1978). Psychometric methods. New York: McGraw-Hill.

OECD. (2005). Organisation for Economic Cooperation and Development. Oslo Manual. Guidance on the collection and interpretation of data on innovation. Luxembourg: OECD.

OECD. (2014). Organisation for Economic Co-operation and Development. Perspectivas de la OCDE sobre ciencia, tecnología e industria 2014 (Version abreviada) Informe Iberoamericano: Informe Iberoamericano (OECD Publishing Ed.). Luxembourg: OECD Publishing. https://doi.org/10.1787/dcr-2014-en

Ordóñez de Pablos, P. (2004). Measuring and reporting structural capital: Lessons from European learning firms. Journal of Intellectual Capital, 5(4), 629-647. https://doi.org/10.1108/14691930410567059

Petty, R., \& Guthrie, J. (2000). Intellectual capital literature review: measurement, reporting and management. Journal of Intellectual Capital, 1(2), 155-176. https://doi.org/10.1108/14691930010348731

Porter, M. E. (2011). Competitive advantage of nations: creating and sustaining superior performance. New York: Simon and Schuster.

Quinn, D., \& Shapiro, R. Y. (1991). Economic growth strategies: The effects of ideological partisanship on interest rates and business taxation in the United States. American Journal of Political Science, 656-685. https://doi.org/10.2307/2111560

Raju, P. S., Lonial, S. C., \& Crum, M. D. (2011). Market orientation in the context of SMEs: A conceptual framework. Journal of Business Research, 64(12), 1320-1326. https://doi.org/10.1016/j.jbusres.2010.12.002

Rappert, B., Webster, A., \& Charles, D. (1999). Making sense of diversity and reluctance: academic-industrial relations and intellectual property. Research Policy, 28(8), 873-890. https://doi.org/10.1016/S0048-7333(99)00028-1

Raymond, L., Bergeron, F., Croteau, A. M., \& St-Pierre, J. (2016). IT-enabled Knowledge Management for the Competitive Performance of Manufacturing SMEs: An Absorptive Capacity-based View. Knowledge \& Process Management, 23(2), 110-123. https://doi.org/10.1002/kpm.1503

Ringle, C. M., Sarstedt, M., \& Straub, D. (2012). A critical look at the use of PLS-SEM in MIS Quarterly. MIS Quarterly (MISQ), 36(1).

Ringle, C. M., Wende, S., \& Becker, J. M. (2014). SmartPLS 3. SmartPLS, Hamburg.

Roberts, P., Priest, H., \& Traynor, M. (2006). Reliability and validity in research. Nursing Standard, $20(44), 41$. https://doi.org/10.7748/ns.20.44.41.s56

Roos, G., \& Roos, J. (1997). Measuring your company's intellectual performance. Long Range Planning, 30(3), 413-426. https://doi.org/10.1016/S0024-6301(97)90260-0

Rosenbusch, N., Brinckmann, J., \& Bausch, A. (2011). Is innovation always beneficial? A meta-analysis of the 
relationship between innovation and performance in SMEs. Journal of Business Venturing, 26(4), 441-457. https://doi.org/10.1016/j.jbusvent.2009.12.002

Sigler, K. J. (2011). CEO Compensation and company performance. Business and Economic Journal, 2011, 1-8.

Smith, M. H., \& Smith, D. (2007). Implementing strategically aligned performance measurement in small firms. International Journal of Production Economics, 106(2), 393-408. https://doi.org/10.1016/j.ijpe.2006.07.011

Spithoven, A., Clarysse, B., \& Knockaert, M. (2011). Building absorptive capacity to organise inbound open innovation in traditional industries. Technovation, 31(1), 10-21. https://doi.org/10.1016/j.technovation.2010.10.003

Teece, D. J. (2007). Explicating dynamic capabilities: the nature and microfoundations of (sustainable) enterprise performance. Strategic Management Journal, 28(13), 1319-1350. https://doi.org/10.1002/smj.640

Teece, D. J. (2009). Dynamic capabilities and strategic management: organizing for innovation and growth. Oxford: OUP.

Terziovski, M. (2010). Innovation practice and its performance implications in small and medium enterprises (SMEs) in the manufacturing sector: a resource-based view. Strategic Management Journal, 31(8), 892-902. https://doi.org/10.1002/smj.841

Todorova, G., \& Durisin, B. (2007). Absorptive capacity: Valuing a reconceptualization. Academy of Management Review, 32(3), 774-786. https://doi.org/10.5465/AMR.2007.25275513

Urbach, N., \& Ahlemann, F. (2010). Structural equation modeling in information systems research using partial least squares. Journal of Information Technology Theory and Application, 11(2), 5-40.

Vandenberg, R. J., \& Lance, C. E. (2000). A review and synthesis of the measurement invariance literature: Suggestions, practices, and recommendations for organizational research. Organizational Research Methods, 3(1), 4-70. https://doi.org/10.1177/109442810031002

Walker, R. M., Brewer, G. A., Boyne, G. A., \& Avellaneda, C. N. (2011). Market orientation and public service performance: new public management gone mad? Public Administration Review, 71(5), 707-717. https://doi.org/10.1111/j.1540-6210.2011.02410.x

Wang, Y., Chen, Y., \& Benitez-Amado, J. (2015). How information technology influences environmental performance: empirical evidence from China. International Journal of Information Management, 35(2), 160-170. https://doi.org/10.1016/j.ijinfomgt.2014.11.005

Wetzels, M., Odekerken-Schröder, Gaby, \& Van Oppen, Claudia. (2009). Using PLS path modeling for assessing hierarchical construct models: Guidelines and empirical illustration. MIS Quarterly, 177-195.

WIPO. (2004). World Intellectual Property Organization. Intellectual Property Handbook: Policy, Law and Use: World Intellectual Property Organization.

Wonglimpiyarat, J. (2015). New economics of innovation: Strategies to support high-tech SMEs. The Journal of High Technology Management Research, 26(2), 186-195. https://doi.org/10.1016/j.hitech.2015.09.006

Zahra, S. A., \& George, G. (2002). Absorptive capacity: A review, reconceptualization, and extension. Academy of Management Review, 27(2), 185-203.

Zahra, S. A., \& George, G. (2002). Absorptive Capacity: A Review, Reconceptualization, and Extension. The Academy of Management Review, 27(2), 185. https://doi.org/10.2307/4134351

\section{Copyrights}

Copyright for this article is retained by the author(s), with first publication rights granted to the journal.

This is an open-access article distributed under the terms and conditions of the Creative Commons Attribution license (http://creativecommons.org/licenses/by/4.0/). 